\title{
Capabilities of Hydrogen as a Supplementary Fuel for Compression Ignition Engines - A Review
}

\author{
Mihail Peychev
}

\begin{abstract}
The current article describes the process of conversion of a compression ignition (diesel) engine to dual-fuel engine, operating with diesel fuel and hydrogen simultaneously. Properties of hydrogen - physical and chemical and the qualities of hydrogen as fuel are analyzed. Different methods for hydrogen storage - physical, chemical and adsorption are described. Special attention is paid to precautions when operating with hydrogen and the elements needed to use during engine conversion, in order to ensure safe hydrogen-diesel operation. Two hydrogen injection options are possible hydrogen direction injection and port injection at engine intake. Both are explained. A short analysis of approximate conversion costs for dual-fuel operation is made. Hydrogen gas price is also noticed. The final part of the article does a brief review on the research of several authors about hydrogen-diesel dual fuel operation in compression ignition engines. Results from these authors research, considering engine performance, economy and emissions, as well as combustion process parameters, are cited. As these studies define a coefficient used to determine hydrogen share in total fuel (diesel fuel plus hydrogen) the current article analyses the influence of changing hydrogen share in fuel on engine operation. Authors different experiments are taken into account in order to assess the influence of growing hydrogen content in fuel on engine economy and emissions, including total and specific fuel consumption, thermal efficiency, exhaust gas opacity, nitrogen oxides concentration etc. As authors have controversial opinions in some cases influence of hydrogen is considered positive or negative depending on how much authors claim positive and how much claim negative influence. Results from the review concerning effects of hydrogen on diesel engine operation are summarized in a table for easier perception.
\end{abstract}

Index Terms- dual-fuel operation, hydrogen, hydrogen-diesel engine, hydrogen in internal combustion engines

\section{INTRODUCTION}

Hydrogen is being widely discussed as fuel of the future in the last few years. Huge investments are done in this direction in order to ensure the development of hydrogen economy. Either as fuel for internal combustion engines or fuel cells, it will play a big role as an energy carrier in the future production of road vehicles (for personal use, for passenger and cargo transportation), of marine vehicles and other aspects of industry. Yet, compression ignition engines running on diesel fuel, which are considered the engines with higher pollution compared to spark ignition engines, still play an important role in the powertrain of trucks and intercity buses. Also, a lot of them, produced in the last decade, still operate as a mechanical power source for personal automobiles. Cleaner fuels, such as hydrogen, propose a

Mihail Hristov Peychev, Department of Combustion Engines, Automobile Engineering and Transport, Technical University of Sofia, Sofia, Bulgaria, 359887894828. simple and way of improving engine economy and emissions. Unfortunately, hydrogen can be hardly used as a single fuel in a diesel engine due to the lack of a way to ignite it, so it is mostly used as a supplementary fuel. This process is referred as dual fuel combustion or gas-diesel cycle operation. Such operation usually has a positive influence on engine emissions. It is performed by injecting two types of fuel in the engine simultaneously. Diesel fuel is injected directly in the cylinder and hydrogen is injected either directly in the cylinder or in the intake manifold. Hydrogen however influences on a number of other engine indicators performance, economy and combustion process parameters. There is a lot of research dedicated to this influence.

\section{PURPOSE OF THE STUDY}

The purpose of the current study is to make an assessment of the possibilities to integrate hydrogen as supplementary fuel in existing and future 4-stroke compression ignition engines, by analysis of research of different authors on the influence that hydrogen has on performance, economy, emissions and combustion process parameters of these engines. Hydrogen properties, storage options, necessary precautions, conversion possibilities and gas costs are also taken into account.

\section{PROPERTIES OF HYDROGEN AND STORAGE METHODS}

Major physical and chemical properties of hydrogen are shown in table 1 and table 2 [1], [2]. These properties determine its qualities as fuel for internal combustion engines. The also define storage requirements and necessary precautions.

One of the greatest advantages of hydrogen over diesel fuel is its high lower heating value $(120 \mathrm{MJ} / \mathrm{kg}$ against 42,4 $\mathrm{MJ} / \mathrm{kg}$ ). Its greatest drawback is the extremely low density under normal conditions. So it brings much higher energy, but this energy cannot enter the engine due to the high volume that hydrogen takes. The only available option to fully solve this problem is direct injection of the gas during compression stroke.

Table 1-Physical properties of hydrogen

\begin{tabular}{|l|l|}
\hline Property & Value \\
\hline Melting Point & $13,99 \mathrm{~K}\left(-259,16^{\circ} \mathrm{C}\right)$ \\
\hline Boiling point & $20,271 \mathrm{~K}\left(-252,879{ }^{\circ} \mathrm{C}\right)$ \\
\hline $\begin{array}{l}\text { Physical state under } \\
\text { normal conditions }\end{array}$ & Gaseous \\
\hline Smell & No smell \\
\hline Colour & Colourless \\
\hline Density under normal & $0,08999 \mathrm{~kg} / \mathrm{m}^{3}$ \\
\hline
\end{tabular}




\begin{tabular}{|l|l|}
\hline conditions & \\
\hline Molecular formula & $\mathrm{H}_{2}$ \\
\hline Toxicity & Not toxic \\
\hline Higher heating value & $141900 \mathrm{~kJ} / \mathrm{kg}$ \\
\hline Lower heating value & $120000 \mathrm{~kJ} / \mathrm{kg}$ \\
\hline Specific heat capacity & $\begin{array}{l}13-21 \mathrm{~kJ} / \mathrm{kg} . \mathrm{K} \text { for temperature } \\
\text { variation from } 175 \mathrm{~K} \text { to } 6000 \mathrm{~K}\end{array}$ \\
\hline
\end{tabular}

Chemical reaction with oxygen (1) is among hydrogen's most important properties.

$$
2 \mathrm{H}_{2}+\mathrm{O}_{2} \rightarrow 2 \mathrm{H}_{2} \mathrm{O}+\mathrm{Q}(1)
$$

Only water and heat are produced by the reaction. Large flammability limits are also important - they can be considered both - advantage and drawback. They make it possible for the engine to run with a big range of air-fuel ratios and also promise a flame velocity, higher than the one of conventional fuels. However the lack of smell and colour, combined with the high flammability, demands certain precautions in order to operate with hydrogen safely.

Table 2-Chemical properties of hydrogen

\begin{tabular}{|l|l|}
\hline Reactants & Reaction products \\
\hline $\begin{array}{l}\text { Reactivity } \\
\text { with air and } \\
\text { oxygen }\end{array}$ & $\begin{array}{l}\text { Reacts with oxygen (pure oxygen or air) to } \\
\text { form water. }\end{array}$ \\
\hline $\begin{array}{l}\text { Reactivity } \\
\text { with gases }\end{array}$ & $\begin{array}{l}\text { Reacts with carbon monoxide, fluorine, } \\
\text { chlorine, nitrogen and others, at } \\
\text { temperatures higher than room } \\
\text { temperature. At high temperature and } \\
\text { pressure it reacts with nitrogen (pure } \\
\text { nitrogen or air) to form ammonia. Reacts } \\
\text { with carbon dioxide to form methanol. } \\
\text { Does not interact with inert gases. }\end{array}$ \\
\hline Flammability \\
& $\begin{array}{l}\text { Extremely flammable gas. Forms explosive } \\
\text { mixtures with oxygen and chlorine. They } \\
\text { are easily ignited by contact with a spark, } \\
\text { open flame, highly heated surface or } \\
\text { prolonged exposure to sunlight. Ignition } \\
\text { limits in a mixture with air are 4-75\% by } \\
\text { volume of hydrogen. In an oxygen mixture } \\
\text { the flammability limits are: 4-94\% by } \\
\text { volume of hydrogen, and with chlorine: } \\
\text { 5-95\%. }\end{array}$ \\
\hline
\end{tabular}

There are two main methods for hydrogen storage physical storage and chemical storage [3]. A third method, which can be considered physical, chemical, or a combination of both, is adsorption.

Physical methods are the most utilized due to their simplicity compared to other methods. Their biggest advantage is the higher speed of charge and discharge. These methods rely on storage under high pressure, under low temperatures (hydrogen is in liquid state) or a combination of both. Storage under high pressure is done using type 3 and type 4 tanks, defined in the EN ISO 11439:2000. They have an internal metal (usually an aluminium alloy) or plastic liner and a shell made of composite materials [4], [5]. Hydrogen is kept in these vessels under pressure of 350 or 700 bar.

Another physical method - storage under low temperature, is done by cooling hydrogen gas down to temperatures below $20 \mathrm{~K}$ (just below boiling point, table 1) in order to transform it into liquid. Then hydrogen is stored into a special fuel tank. At this temperature hydrogen has a density of $70 \mathrm{~kg} / \mathrm{m} 3$. A big drawback of this method is the energy needed to cool down the gas. It is about $30 \%$ of the energy which the gas itself contains [6]. Another problem is the need of tank with two shells, with several different layers of insulation in between, which is necessary in order to keep hydrogen from warming up and expanding [7]. The third option for physical storage is cryo-compressed hydrogen. Hydrogen is liquefied at temperature lower than $20 \mathrm{~K}$ and then stored into fuel tank under 350 bars of pressure. A much higher density of the gas is achieved with this method. It is used in a Toyota Prius prototype and proves a much higher possible travel distance [7]. The most important drawback of all the physical methods however, is the higher risk of explosion compared to other methods.

In chemical methods hydrogen is stored by forming chemical compounds, such as hydrides, ammonia, formic acid, carbohydrates [8], complex hydrocarbons etc., with other chemical elements. When engine is operating the compounds are being broken thus releasing hydrogen. Usually the process requires a catalyst - certain pressure or temperature. Among the chemical compounds hydrides are one of the most frequently used hydrogen carriers. They are formed by the general reaction:

$$
\mathrm{k}_{1} \mathrm{M}+\mathrm{k}_{2} \mathrm{H}_{2} \rightarrow \mathrm{k}_{3} \mathrm{MH}_{\mathrm{n}}(2)
$$

where: $\mathrm{M}$ is metal - lithium, sodium, potassium, aluminium, etc.; $\mathrm{k}_{1}-\mathrm{k}_{3}$ are coefficients to balance the equation; $\mathrm{n}$ is number of hydrogen atoms in the hydride. Complex metal hydrides [7], which consist of 2 or more metals and hydrogen, such as $\mathrm{NaAlH}_{4}$, can also be formed [9]-[10]. By now hydrates are the most promising of the chemical storage methods. They have a high gravimetric energy density and a decomposition of the compound can be achieved relatively easy. The most important advantage of chemical storage methods is the lower risk of explosions. The compounds are stable, no losses from evaporation or accidental leak of hydrogen are possible. Unfortunately the stability is a barrier for achieving high speeds of fuel charge and discharge. Problems with recycling are also present.

Adsorption is a process of containing hydrogen on the surface of a certain material [6], [7]. The forces of adhesion are relatively weak so the discharge of hydrogen is easier compared to chemical methods. The materials used are mostly different forms of carbon: fullerene, carbon nanotubes, graphite, graphene, zeolites etc. This method is relatively cheap and the risk of accidents is low, like the chemical methods. Still hydrogen has to be charged under low temperatures and high pressure.

\section{PRECAUTIONS AND CONVERSION OPTIONS}

Most of the precautions for the hydrogen use are taken at the stage of fuel tank production. Tanks are tested in extreme conditions and are able to withstand different and very high loads [11]. Still there are other precautions that should be taken care of. At least one sensor for hydrogen concentration in air should be mounted in the vehicle or in the area of hydrogen storage. Most sensors generate a signal when hydrogen content in the air is above $0,25 \%$. A flashback arrestor (one-way valve) is also required along 
the fuel line. The valve should stop an eventual wave of pressure, caused by explosion somewhere in the fuel line, to reach the fuel tank. The fuel line itself should be composed of elements which are resistant to hydrogen embrittlement [12][13]. Many metals, including some types of steel have a crystal structure which permits hydrogen molecules to enter between adjacent atoms of the metal. This phenomenon can cause dangerous failures of some fuel line elements. Thus, materials for hydrogen feed should be picked up carefully. Along with this securing a good sealing of the fuel line connections is also essential.

A conversion of a diesel engine for dual fuel operation requires a secondary fuel system to inject the hydrogen. Such fuel system consists of a hydrogen fuel tank, fuel line, including a check valve and a fuel shot-off valve, pressure regulator (one or two as pressure may need to be reduced in two stages), hydrogen injectors, sensor (one or more) for hydrogen concentration in the surrounding air and an engine electronic control unit (ECU). ECU is used to control hydrogen injection timing and to shut off hydrogen fuel supply if a signal is received from the sensor for hydrogen concentration. These elements can be used for converting any vehicle with diesel engine to operate with diesel and hydrogen in dual-fuel mode - automobiles, trucks, buses, agricultural technique, locomotives or other. Similar conversion for a spark ignition engine is made by D. Sáinz, P.M. Diéguez, C. Sopena, J.C. Urroz and L.M. Gandía [14]. Their research represents data acquired from the operation of a fully functional small commercial vehicle running on hydrogen.

There are two possible ways to inject hydrogen - directly in to the cylinder or in the engine intake manifold. The direct injection is more beneficial in terms keeping the engine volumetric efficiency. However it requires injectors with a special design, which are able to withstand the high temperature and pressure [15]. Indirect injection is simpler to achieve - injectors are mounted on the engine intake manifold and fuel is injected before the intake valve [16][17]. This type of injection is worse for the volumetric efficiency due to the high volume of hydrogen in the intake. No matter the pressure at which hydrogen is stored, once injected in the manifold, its density becomes $\sim 0,1 \mathrm{~kg} / \mathrm{m}^{3}$ depending on the temperature. Thus there is less space in the intake manifold and less air enters the engine. Direct injection is the more profitable way of conversion, but due to the high complexity of injectors there is very little research on it. Finding a place to mount the injector in the combustion chamber of an engine with 4 valves per cylinder is also a big challenge. So at this stage of fuel systems development, hydrogen is more frequently injected into the intake manifold.

\section{CONVERSION COSTS AND GAS COSTS}

Basic economic calculations are an essential aspect of the diesel engine conversion process. The total conversion costs may have a value greater than the value of the engine or the vehicle itself. Hydrogen purchased from hydrogen stations in Europe and USA is also more expensive than diesel fuel (the higher lower heating value of hydrogen is taken into account). A brief description of the conversion costs is presented in table 3 .
Table 3-Costs for hydrogen conversion

\begin{tabular}{|l|c|c|c|}
\hline $\begin{array}{l}\text { Element from the } \\
\text { hydrogen fuel } \\
\text { system }\end{array}$ & Quantity & $\begin{array}{l}\text { Price per } \\
\text { 1pc }\end{array}$ & $\begin{array}{l}\text { Price } \\
\text { total }\end{array}$ \\
\hline \multicolumn{1}{|c|}{ - } & - & EUR & EUR \\
\hline $\begin{array}{l}\text { Hydrogen type 4 } \\
\text { tank and storage } \\
\text { system [18]-[20] }\end{array}$ & 1 & 1900 & 1900 \\
\hline Pressure regulator & $1(2)$ & $50-100$ & $50-100$ \\
\hline $\begin{array}{l}\text { Hydrogen for } \\
\text { injectors rail in }\end{array}$ & 1 & 5 & 15 \\
\hline $\begin{array}{l}\text { Sensor } \\
\text { hydrogen } \\
\text { concentration } \\
\text { air }\end{array}$ & 3 & 30 & 30 \\
\hline $\begin{array}{l}\text { Hydrogen pressure } \\
\text { sensor }\end{array}$ & 1 & 25 & 25 \\
\hline $\begin{array}{l}\text { Hydrogen } \\
\text { temperature sensor }\end{array}$ & 1 & 500 & 300 \\
\hline $\begin{array}{l}\text { ECU for the } \\
\text { hydrogen } \\
\text { system }\end{array}$ & 1 & - & $2580 €$ \\
\hline Hoses & 15 & & \\
\hline Wiring & - & 50,2 & 10 \\
\hline Total costs & & & \\
\hline
\end{tabular}

Prices in table 3 are average prices for the components, gathered from different online stores, US Department of Energy and other sources. Market for hydrogen storage systems, sensors and other products, related to hydrogen fuel injection, is relatively young and going under rapid development. Supply and demand of hydrogen goods also differ greatly in various regions in the world. Prices change daily. Thus it is extremely hard to find reliable data and predict the accurate component prices. Prices can also vary depending on the engine parameters, the vehicle which is driven by the engine, components mounting possibilities, etc. For example a rail with $\mathrm{CNG}$ injectors is suitable for hydrogen, but price can vary depending on the number of cylinders. Length of hoses and wiring can vary too. ECUs are also from different categories and their price can vary from 150 to more than $5000 €$. After adding all the component prices, the total conversion costs reach about $2600 €$ without taking into account the labour expenses. This is a very low price compared to [14] where authors claim that the total conversions costs are $6000 €$ and 200 man-hours (year is 2012). One reason for the big difference is the use of 2 hydrogen tanks in [14] which are the most expensive components in the conversion process. The difference also shows the fast market and price development. Dropping storage system prices during the period 2013-2018 can also be seen in [21].

Hydrogen gas costs can vary in different regions of the world. In the EU price is 9,5 EUR/kg in every hydrogen station [22]. In California, USA the average price of hydrogen for 2019 is $\sim 16 \$ / \mathrm{kg}$ [23]. This price is several times higher than the price of diesel fuel.

\section{INFLUENCE OF HYDROGEN ON PERFORMANCE, ECONOMY AND EMISSIONS OF A COMPRESSION IGNITION ENGINE}

The predominant part of research done on hydrogen conversion and the influence of hydrogen on performance, 
economy and emissions is done by varying hydrogen share in the total fuel (diesel fuel + hydrogen) at constant engine speed and power (torque). Most researchers define a coefficient based whether on the energy share or on the fuel consumption of each fuel. In the case of energy share the coefficient is expressed by the formula:

$$
K_{H 2-E}=\frac{E_{H 2}}{E_{H 2}+E_{D F}} \cdot 100, \% \text { (4) }
$$

where $E_{H 2}$ and $E_{D F}$ are the energies brought with each fuel. Same coefficient can be expressed in terms of fuel consumption:

$$
K_{H 2-F C}=\frac{G_{H 2}}{G_{H 2}+G_{D F}} \cdot 100, \%(5)
$$

where $G_{H 2}$ and $G_{D F}$ are fuel consumptions of hydrogen and diesel fuel respectively and can be measured in [ $\mathrm{kg} /$ cycle] or $[\mathrm{kg} / \mathrm{h}]$. Both coefficients are related as energy brought with the corresponding fuel per cycle $\left(E_{f}\right)$ can be expressed with the equation:

$$
E_{f}=m_{f} \cdot L_{h-f},[k J](6)
$$

where $m_{f}$ is the mass of fuel injected in one engine cycle $[\mathrm{kg}]$ and $L_{h-f}$ is the lower heating value of fuel $[\mathrm{kJ} / \mathrm{kg}]$. The main purpose with these coefficients is to assess the change in engine performance, emissions, economy and combustion process as a function of the hydrogen quantity in fuel. Influence of hydrogen for most of these parameters is discussed below.

\section{A. Influence on total fuel consumption and specific fuel consumption}

Most of researchers unite around the thesis that hydrogen substitution and growing hydrogen share in fuel has a positive influence on the specific fuel consumption. A study of Juknelevicius, Szwaja, Pyrc and Gruca [24] shows a drastic reduction is the specific fuel consumption as a function of hydrogen energy share at all engine loads. Total fuel consumption also drops as it is a function of the specific fuel consumption and engine power (which is kept constant). Hamdan, Selim, Al-Omari and Elnajjar performed an investigation which confirms that increasing hydrogen leads to lower specific fuel consumption [25]. Other sources also confirm the positive influence of hydrogen on fuel economy [26], [27]. Yet, there is a limited amount of research which shows a negative influence of hydrogen on efficiency and economy [28].

\section{B. Influence on total efficiency}

Total engine efficiency is related to specific fuel consumption and the average lower heating value of the fuel mixture. Thus a positive influence of hydrogen on specific fuel consumption should lead to positive influence on total efficiency [25], [27]. A research of Tsujimura and Suzuki [29] shows the influence of different hydrogen energy share on thermal efficiency for 3 different engine loads. At light load hydrogen has ambiguous effect on efficiency. At medium and high engine loads growing hydrogen energy share has a positive impact on engine thermal efficiency. The research presented in [24] claims that hydrogen has a positive effect on specific fuel consumption at all engine modes. However the thermal efficiency depends not only on hydrogen share but on engine load too. Yet, at most engine loads increasing share of hydrogen has positive or no influence on efficiency. A study of Lata, Misra and Medhekar also shows a strong dependency of hydrogen influence on efficiency from engine load [30]. Again hydrogen influence is better at high loads than at low loads. Another parameter that has strong impact on thermal efficiency is engine volumetric efficiency. Unfortunately none of the cited research presents results about it as a function of hydrogen share in fuel.

\section{Influence on emissions}

Hydrogen should at first thought have positive influence on engine emissions as products from hydrogen combustion are water and heat. Its high flame speed however leads to rising in-cylinder temperature and pressure, compared to diesel fuel operation, which are conditions suitable for nitrogen oxides formation. This however, combined with the good mixture formation of hydrogen and air, should lead to better combustion and thus lower levels of unburned carbon and exhaust gas opacity. Influence of hydrogen on each toxic component is analysed below.

Influence on exhaust gas opacity. Researchers are consistent about the benefits of increasing hydrogen fuel share regarding exhaust gas opacity (smokiness). Some of the authors show drastic improvement (opacity several times lower, compared to work on diesel fuel only) [24], [31], [32]. Other researchers show a less significant, but still positive effect of increasing hydrogen fuel share on engine smoke emissions [25], [29]. Impact of hydrogen on this emission component can be considered positive at all engine modes.

Influence on nitrogen oxides $\left(N O_{x}\right)$. Influence of hydrogen fuel on nitrogen oxides $\left(\mathrm{NO}_{\mathrm{x}}\right)$ is highly variable, mostly depending on engine load. Some authors represent results with slight positive or neutral hydrogen influence on the $\mathrm{NO}_{x}$ concentration in exhaust gases [25], [27], [29], [31]. Results with rising levels of $\mathrm{NO}_{\mathrm{x}}$ in function of hydrogen content however are more clear and pronounced [24], [32], [33], [34]. Thus the influence of hydrogen at this emission component is considered negative.

Influence on hydrocarbons (HC). Hydrocarbons (HC), like $\mathrm{NO}_{\mathrm{X}}$, also vary as a function of engine load. According to [27] the gaseous fuel has positive influence on the concentration of hydrocarbons in exhaust gases at all engine loads. According to the results in [29] however, the influence of hydrogen on hydrocarbons concentration is neutral or slightly negative at low to medium load and strongly positive at high load. Results in [24] show a positive influence of growing hydrogen share on the level of hydrocarbons. The experiments in [31], which are made at different compression ratios, apart from the different hydrogen energy share, show ambiguous results - at low and medium compression ratio hydrogen has slightly negative or neutral influence. At high compression ratio the influence on total hydrocarbons is strongly positive. Results in [32] and [34] show negative effect of increasing hydrogen share on total HC which is better expressed in [34].

Influence on carbon monoxide $(\mathrm{CO})$ and carbon dioxide $\left(\mathrm{CO}_{2}\right)$. All the authors claim that increasing hydrogen in total fuel reduces the carbon dioxide $\left(\mathrm{CO}_{2}\right)$ concentration in the exhaust gas [24], [27], [29], [32]. Effect on carbon monoxide (CO) concentration is also positive [26], [29], [31], [32] [34] Only in [30] authors show a negative influence of hydrogen on $\mathrm{CO}$ concentration. 


\section{INFLUENCE OF HYDROGEN ON THE COMBUSTION PROCESS OF A COMPRESSION IGNITION ENGINE}

The nature of combustion process and its parameters very much define the engine performance, economy and emissions. Combustion process parameters are also an important measure for the engine mechanical and thermal load. Therefore it is essential to know what influence hydrogen has on these parameters.

\section{A. Influence on in-cylinder pressure}

Like some of the parameters mentioned above, the influence of hydrogen on in-cylinder pressure strongly depends on engine load. Most authors show a decrease in maximum in-cylinder pressure with increasing hydrogen share at low loads. At high loads hydrogen has no influence or leads to an increase of maximum pressure [28], [30], [34], [35]. The study done by Yilmaz and Gumus however shows a higher maximum in-cylinder pressure with increasing hydrogen share at low load [27]. At high load the maximum pressure does not change significantly compared to combustion with diesel fuel only. A study, done by Mirica, Cernat, Pana, Negurescu and Nutu [36], represents a diagram of the maximum in-cylinder pressure as a function of fuel substitution (hydrogen share) at $40 \%$ engine load. Result is a rising maximum pressure with growing hydrogen share. So there are different possibilities for hydrogen influence on the maximum in-cylinder pressure. It depends on engine load and speed, diesel injection timing, engine specifications (number of cylinders, cooling system, shape of combustion chamber) etc. Higher in-cylinder pressure usually means more mechanical work produced by the engine, thus higher total efficiency. Unfortunately such pressure leads to higher mechanical load on engine parts which can result in severe damages as engine is calculated for diesel fuel operation with a certain maximum pressure in the combustion chamber. Exceeding this pressure may lead to negative consequences.

\section{$B$. Influence on cylinder pressure rise rate}

There is less research on the pressure rise rate in the engine combustion chamber than on in-cylinder pressure or rate of heat release. Yet pressure rise rate is an important parameter, an indicator for dynamic mechanical load on engine parts. Pressure rise rate, higher than $1 \mathrm{MPa} /{ }^{\circ}$ (crankshaft rotation) is unacceptable as it can lead to engine failure [32], [37]. All results show that increasing hydrogen share leads to higher pressure rise rates at high engine loads [31], [32], [36], [38]. This corresponds to the high speed of propagation of hydrogen flame. Yet, a slight reduction in pressure rise rate is possible at low engine loads [38]. So hydrogen content should be limited, especially at high engine load in order to keep engine parts within the calculated static and dynamic mechanical load.

\section{Influence on heat release rate}

Curves representing the heat release rate in the engine can vary and depend on a number of engine operating parameters, including: injection timing of diesel fuel, engine speed and load, hydrogen injection timing, hydrogen energy share etc. Thus it is difficult to isolate and analyse the influence of hydrogen energy/mass share. Yet some conclusions can be made, mostly regarding the maximum value of heat release rate. Growing hydrogen share in fuel usually leads to growing maximum heat release rate [32], [34], [39], [40]. Authors in [27] give the opposite statement - in their research higher hydrogen content lead to lower maximum value of heat release rate, no matter the engine load. In [35] the influence varies according to engine load - at low load hydrogen has no influence on maximum heat release rate, at medium engine load growing hydrogen share leads to reduction of the maximum rate of heat release and at high load increasing hydrogen content leads to increasing maximum value of heat release rate. The effect of hydrogen on ignition delay is also ambiguous. Results in [35] show that an increasing level of hydrogen causes a bigger ignition delay at all engine modes. The research results presented in [27], [32], [34] and [39] claim that hydrogen has no influence on ignition delay. Results in [39] are ambiguous - increasing hydrogen content can lead to bigger or smaller ignition delay depending on diesel fuel injection timing, engine load and speed.

The influence of hydrogen on engine performance, economy, emissions and combustion process parameters of a diesel engine running in dual-fuel mode is summarized in table 4.

Table 4 - Influence of hydrogen on performance, economy, emissions and combustion process parameters

\begin{tabular}{|l|l|l|}
\hline Parameter & $\begin{array}{l}\text { Hydrogen } \\
\text { influence in } \\
\text { brief }\end{array}$ & $\begin{array}{l}\text { Influence of growing } \\
\text { hydrogen content in } \\
\text { fuel }\end{array}$ \\
\hline $\begin{array}{l}\text { Total fuel } \\
\text { consumption and } \\
\text { specific fuel } \\
\text { consumption }\end{array}$ & Positive & $\begin{array}{l}\text { Lower total and } \\
\text { specific fuel } \\
\text { consumption, better } \\
\text { engine economy }\end{array}$ \\
\hline Total efficiency & Positive & $\begin{array}{l}\text { Better or unchanged } \\
\text { total efficiency }\end{array}$ \\
\hline $\begin{array}{l}\text { Exhaust gas } \\
\text { opacity }\end{array}$ & Positive & $\begin{array}{l}\text { Lower levels of } \\
\text { exhaust gas opacity }\end{array}$ \\
\hline $\begin{array}{l}\text { NO } \\
\text { concentration }\end{array}$ & Negative & $\begin{array}{l}\text { Higher concentrations } \\
\text { of NO }\end{array}$ \\
\hline $\begin{array}{l}\text { HC } \\
\text { concentration }\end{array}$ & Neutral & $\begin{array}{l}\text { Higher and lower } \\
\text { concentrations of HC. } \\
\text { Ambiguous results. }\end{array}$ \\
\hline $\begin{array}{l}\text { CO and } \mathrm{CO}_{2} \\
\text { concentration }\end{array}$ & Positive & $\begin{array}{l}\text { Lower concentration } \\
\text { of CO and CO }\end{array}$ \\
\hline $\begin{array}{l}\text { Maximum } \\
\text { in-cylinder } \\
\text { pressure }\end{array}$ & Neutral & $\begin{array}{l}\text { Depending on engine } \\
\text { load, speed, diesel } \\
\text { fuel injection } \\
\text { parameters. } \\
\text { Ambiguous results. }\end{array}$ \\
\hline $\begin{array}{l}\text { Maximum } \\
\text { pressure rise rate }\end{array}$ & Negative & $\begin{array}{l}\text { Higher maximum } \\
\text { pressure rise rate. }\end{array}$ \\
\hline Neutral & $\begin{array}{l}\text { Higher maximum heat } \\
\text { release rate. No (or in } \\
\text { less cases }- \text { variable) } \\
\text { effect on ignition } \\
\text { delay. }\end{array}$ \\
\hline
\end{tabular}

\section{CONCLUSIONS}

A conversion of a diesel engine for dual fuel operation with hydrogen can be analyzed in a lot of aspects. Some of 
these aspects are: design tasks (storage options, precautions and conversion options), conversion costs and fuel costs and influence on engine economy, emissions and combustion process parameters. Several conclusions can be made, regarding these aspects:

- Among the existing storage methods, the physical methods, and storage under high pressure in particular, are the only applicable methods for diesel engine conversion;

- Precautions have to be taken when working with hydrogen, including - installation of sensors for hydrogen content in air, installation of flashback arrestors, hydrogen shut-off valve etc.;

- Realization of direct injection of hydrogen, despite its advantages, is hard to achieve and therefore indirect port injection is used more commonly. This option however, has a negative influence on the engine volumetric efficiency;

- Costs for conversion of a diesel engine for diesel-hydrogen operation are higher than costs for conversion to a diesel-LPG or diesel-CNG operation. Price of hydrogen is also higher than the price of conventional fuels;

- Hydrogen has a positive influence on engine fuel consumption and efficiency;

- Hydrogen has a positive influence on exhaust gas opacity, on carbon monoxide (CO) and dioxide concentration (CO2);

- Hydrogen has a negative influence on nitrogen oxides concentration (NOx) and on pressure rise rate in the combustion chamber;

- Influence of hydrogen on hydrocarbons concentration (HC), maximum in-cylinder pressure and maximum heat release rate is ambiguous according to different researchers.

It can be concluded that hydrogen use in compression ignition engines is very beneficial in terms of fuel economy, exhaust gas emissions and combustion process parameters. Compression ignition engines (and spark ignition engines too) may not be the best machines from ecological point of view, but, combined with fuel as energy carrier, they represent the lightest autonomous source of mechanical power. This can have great advantages in certain aspects. Yet several obstacles like storage options, difficulties in direct injection realization and high conversion and fuel costs, have to be settled in order to achieve a mass use of hydrogen in diesel engines.

\section{REFERENCES}

[1] V. Dias, M. Pochet, F. Contino and H. Jeanmart, "Energy and Economic Costs of Chemical Storage", Frontiers in Mechanical Engineering, vol. 6, 2020

[2] https://www.britannica.com/science/hydrogen

[3] Y. Zhang, Z. Jia, Z. Yuan, T. Yang, Y. Qi and D. Zhao, "Development and application of hydrogen storage", Journal of Iron and Steel Research, International, vol. 22, 2015, pp. 757-770

[4] N. Sirosh, Hydrogen Composite Tank Program, "Proceedings of the 2002 U.S. DOE Hydrogen Program Review". Available: https://www.nrel.gov/docs/fy02osti/32405b27.pdf

[5] Th. Hua et-al., Argonne National Laboratory, "Technical Assessment of Compressed Hydrogen Storage Tank Systems for Automotive Applications", 2010, p.52 Available: https://www1.eere.energy.gov/hydrogenandfuelcells/pdfs/compressed tank storage.pdf

[6] F. Zhang, P. Zhao, M. Niu, J. Maddy, "The survey of key technologies in hydrogen energy storage", International journal of hydrogen energy vol. 41, 2016, pp. $14535-14552$
[7] D.J. Durbin, C. Malardier-Jugroot, "Review of hydrogen storage techniques for on board vehicle applications", International journal of hydrogen energy vol. 38, 2013, pp. 14595 - 14617

[8] Y.-H. Zhang, "Renewable carbohydrates are a potential high-density hydrogen carrier", International journal of hydrogen energy vol. 35, 2010, pp. $10334-10342$

[9] W. Chen, L. You, G. Xia, X. Yu, "A balance between catalysis and nanoconfinement towards enhanced hydrogen storage performance of NaAlH4", Journal of Materials Science and Technology, vol. 79, 2021, pp. $205-211$

[10] E. Ianni, M. Sofianos, M. R. Rowles, D. A. Sheppard, T. D. Humphries, C. E. Buckley, "Synthesis of NaAlH4/Al composites and their applications in hydrogen storage", International journal of hydrogen energy vol. 43, 2018, pp. $17309-17317$

[11] Powertech Labs Inc, CNG \& Hydrogen Tank Safety, R\&D, and Testing. Available: https://www1.eere.energy.gov/hydrogenandfuelcells/pdfs/cng h2 wo rkshop_8_wong.pdf

[12] M. L. Martin , M. J. Connolly , F. W. DelRio and A. J. Slifka, "Hydrogen embrittlement in ferritic steels", Applied Physics Reviews, vol. 7,2020

[13] X. Li, X. Ma, J. Zhang, E. Akiyama, Y. Wang, X. Song, "Review of Hydrogen Embrittlement in Metals: Hydrogen Diffusion, Hydrogen Characterization, Hydrogen Embrittlement Mechanism and Prevention", Acta Metallurgica Sinica, vol. 33, pp. 759-773

[14] D. Sáinz, P.M. Diéguez, C. Sopena, J.C. Urroz and L.M. Gandía, "Conversion of a commercial gasoline vehicle to run bi-fuel (hydrogen-gasoline)", International journal of hydrogen energy vol. 37, 2012, pp. $1781-1789$

[15] J.M. Antunes, R. Mikalsen and A.P. Roskilly, "An experimental study of a direct injection compression ignition hydrogen engine", International journal of hydrogen energy vol. 34, 2009, pp. $6516-$ 6522

[16] J. Lee, Ch. Park, Y. Ki, Y. Choi, J. Bae, B. Lim, "Effect of turbocharger on performance and thermal efficiency of hydrogen-fueled spark ignition engine", International journal of hydrogen energy vol. 44, 2019 , pp. $4350-4360$

[17] Ch. Ji, T. Su, Sh. Wang, Bo Zhang, M. Yu and X. Cong, "Effect of hydrogen addition on combustion and emissions performance of a gasoline rotary engine at part load and stoichiometric conditions", Energy conversion and management, vol. 121, 2016, pp. 272-280

[18] https://www.cngunited.com/cng-tanks-2/

[19] Brian D. James Cassidy HouchinsJennie M. Huya- Kouadio Daniel A. DeSantis "Final Report: Hydrogen Storage System Cost Analysis", US Department of Energy, Office of Scientific and Technical Information, 2016. Available: https://www.osti.gov/servlets/purl/1343975

[20] B. D. James and C. Houchins, "700 bar type IV H2 pressure vessel cost projections", Department of Energy Physical-Based Hydrogen Storage Workshop: Identifying Potential Pathways for Lower Cost 700 Bar Storage Vessels, 2016.2 Available: https://www.energy.gov/sites/prod/files/2016/09/f33/fcto_h2_storage _700bar_workshop_2_james.pdf

[21] C. Houchins and B. D. James, "Hydrogen Storage Cost Analysis (ST100)", 2019 DOE Hydrogen and Fuel Cells Program Review, 2019. Available: https://www.hydrogen.energy.gov/pdfs/review19/st100_james 2019 o.pdf

[22] https://h2.live/en

[23] https://cafcp.org/content/cost-refill

[24] R. Juknelevicius, St. Szwaja, M. Pyrc and M. Gruca, "Influence of hydrogen co-combustion with diesel fuel on performance, smoke and combustion phases in the compression ignition engine", International journal of hydrogen energy, vol. 44, 2019, pp. 19026-19034

[25] M. Hamdan, M. Selim, S. Al-Omari and E. Elnajjar, "Hydrogen supplement co-combustion with diesel in compression ignition engine", Renewable Energy, vol. 82, 2015, pp. 54-60

[26] A. Mutluri, R. Gopidesi and S. Valeti, "A Research on the Performance, Emission and Combustion Parameters of the Hydrogen and Biogas Dual Fuel Engine", Incas Bulletin, 2020, vol. 12, pp. $129-136$

[27] I.T. Yilmaz and M. Gumus, "Effects of hydrogen addition to the intake air on performance and emissions of common rail diesel engine", Energy, vol.142, 2018, pp. 1104-1113

[28] W. B. Santosoa, R. A. Bakara and A. Nur, "Combustion characteristics of diesel-hydrogen dual fuel engine at low load", Energy Procedia, vol. 32,2013 , pp. 3-10

[29] T. Tsujimura and Y. Suzuki, "The utilization of hydrogen in hydrogen/diesel dual fuel engine", International journal of hydrogen energy vol. 42, 2014, pp. $14019-14029$ 
[30] D.B. Lata, A. Misra and S. Medhekar, "Effect of hydrogen and LPG addition on the efficiency and emissions of a dual fuel diesel engine", International journal of hydrogen energy vol. 37, 2012, pp. $6084-$ 6096

[31] V. Chintala and K.A. Subramanian, "Experimental investigation of hydrogen energy share improvement in a compression ignition engine using water injection and compression ratio reduction", Energy Conversion and Management, vol. 108, 2016, pp.106-119

[32] W. Tutak, K. Rogaliński and A. Jamrozik, "Combustion and Emission Characteristics of a Biodiesel-Hydrogen Dual-Fuel Engine”, Applied Sciences, vol. 10, 2020, 1082

[33] L. K. S. Teo, A. Tsolakis, A. Megaritis and M. L. Wyszynski, "Hydrogen and Biodiesel Mixtures as Fuels for the Compression Ignition Engine", THIESEL 2002 Conference on Thermo - and Fluid Dynamic Processes in Diesel Engines

[34] Yasin Karagöz, İlker Güler, Tarkan Sandalcı, Levent Yüksek and A. Dalkılıç, "Effect of hydrogen enrichment on combustion characteristics, emissions and performance of a diesel engine", International journal of hydrogen energy vol. 41, 2016, pp. $656-665$

[35] S. Nag, P. Sharma, A. Gupta and A. Dhar, "Combustion, vibration and noise analysis of hydrogen-diesel dual fuelled engine", Fuel, vol. 241, 2019 , pp. 488-494

[36] I. Mirica, A. Cernat, C. Pana, N. Negurescu and C. Nutu, "Performance Comparison Between Hydrogen And Diesel Fuel Fuelled Compression Ignition Engine", Scientific Bulletin Series D, vol.77, 2015, pp. $217-227$

[37] П. Димитров, “Двигатели с вътрешно горене. Част I: Теория на двигателите с вътрешно горене”, 1998г., София, Издателство на ТУ-София, 98

[38] E. Dimitrov, B. Gigov, S. Pantchev, Ph. Michaylov and M. Peychev, "A study of hydrogen fuel impact on compression ignition engine performance", MATEC Web of Conferences, vol. 234, 2018

[39] J. Serrano, F.J. Jiménez-Espadafor and A. López, "Analysis of the effect of different hydrogen/diesel ratios on the performance and emissions of a modified compression ignition engine under dual-fuel mode with water injection. Hydrogen-diesel dual-fuel mode", Energy, vol. 172 2019, pp. 702-711

[40] M. Deb, G.R.K. Sastry, P.K. Bose, R. Banerjee, “An experimental study on combustion, performance and emission analysis of a single cylinder, 4-stroke DI-diesel engine using hydrogen in dual fuel mode of operation", International journal of hydrogen energy vol. 40, 2015, pp. $8586-8598$

Mihail Peychev, male, master. $\mathrm{PhD}$ student in Technical University of Sofia, Faculty of Transport, Department of Combustion Engines, Automobile Engineering and Transport. Speciality of $\mathrm{PhD}$ is "Internal combustion engines".

Education: Bachelor degree in "Accounting and control" from VUZF (University for Insurance and Finances), Sofia, Bulgaria. Bachelor degree in "Transport machinery and technology" from Technical university of Sofia, Bulgaria. Mater degree in "Accounting and control" from University for national and worldwide economy, Sofia, Bulgaria. Master degree in "Transport machinery and technology" from Technical university of Sofia, Bulgaria.

Main research interest is in the field of Internal Combustion Engines. Previous publications can be found at:

https://www.researchgate.net/profile/Mihail_Peychev/resear $\underline{\mathrm{ch}}$

E-mail: m_peychev@tu-sofia.bg or m_peichev@abv.bg

Tel: +359887894828 